\title{
Delay in Diagnosis of Diabetes Mellitus Due to Inaccurate Use of Hemoglobin $\mathrm{A}_{1 \mathrm{C}}$ Levels
}

\author{
Maj Jason G. Arnold USAF, MC, and Maj Howard J. McGowan, USAF, MC
}

Testing of hemoglobin $\mathrm{A}_{1 \mathrm{C}}\left(\mathrm{HbA}_{1 \mathrm{C}}\right)$ levels has become widespread in the management of patients with diabetes mellitus. Since the 1980 s, it has proven to be an invaluable tool correlating with a patient's average blood glucose levels as well as with their disease morbidity. Clinicians often base treatment decisions and make adjustments depending on a patient's $\mathrm{HbA}_{1 \mathrm{c}}$ level. As useful as the $\mathrm{HbA}_{1 \mathrm{C}}$ is, it does have notable limitations. A number of conditions can lead to a falsely elevated or a falsely low $\mathrm{HbA}_{1 \mathrm{C}}$ level. When one of these conditions is present, it is important to recognize the inaccuracy of the $\mathrm{HbA}_{1 \mathrm{c}}$ test to prevent a delay or error in the diagnosis or care of patients with diabetes mellitus. It is also important to be aware of alternative methods of monitoring a patient's diabetes such as a fructosamine assay or home and office blood glucose measurements. Presented is the case of a patient with diabetes mellitus and hereditary spherocytosis, a condition that interfered with her $\mathrm{HbA}_{1 \mathrm{C}}$ value and resulted in a delay in her care. (J Am Board Fam Med 2007;20:93-6.)

Diabetes mellitus afflicts more than 18 million people in the United States at an annual cost of $\$ 92$ billion in direct medical expenses and approximately $\$ 40$ billion in indirect expenses. ${ }^{1}$ In patients with diabetes mellitus and hereditary spherocytosis (or any condition that results in a shortened erythrocyte life span), difficulties can arise with interpretation of hemoglobin $\mathrm{A}_{1 \mathrm{C}}\left(\mathrm{HbA}_{1 \mathrm{C}}\right)$ results. Presented is a patient with hereditary spherocytosis who, partly because of a falsely reassuring $\mathrm{HbA}_{1 \mathrm{C}}$, was not diagnosed with diabetes mellitus despite meeting diagnostic criteria for several years.

\section{Case Presentation}

Mrs. J, a 43-year-old woman, presented to the family medicine clinic for her annual wellness ex-

This article was externally peer reviewed.

Submitted 22 May 2006; revised 22 September 2006; accepted 27 September 2006.

From US Air Force, Medical Corps, 78th Medical Group, Warner-Robbins Air Force Base, GA (JGA); and US Air Force, Medical Corps, Malcolm Grow Medical Center, Andrews Air Force Base, MD (HJM).

Conflict of interest: none declared.

Disclaimer: The opinions and assertions contained herein are the private views of the authors and are not to be construed as official or as reflecting the views of the US Air Force medical departments or the Air Force at large.

Corresponding author: Maj Howard J. McGowan, USAF, MC, Malcolm Grow Medical Center, 79 MDOS, 1075 W. Perimeter Road, Andrews Air Force Base, MD 20762 (E-mail: howard.mcgowan@andrews.af.mil). amination. She had no active complaints and was feeling fine. Her past medical history was significant for gestational diabetes, hyperlipidemia, fatty liver, hereditary spherocytosis, and borderline diabetes. She reported a 30 pack-year smoking history, and her medications included folic acid, a daily multivitamin, and fenofibrate. At the time of evaluation, her physical examination was unremarkable. Review of her laboratory data showed a fasting glucose of $187 \mathrm{mg} / \mathrm{dL}$, a hemoglobin of 10.6 $\mathrm{g} / \mathrm{dL}$, a hematocrit of 0.273 , a total bilirubin of 2.4 $\mathrm{mg} / \mathrm{dL}$, and $\mathrm{HbA}_{1 \mathrm{C}}$ of 0.048 . The remainder of the results from her laboratory examinations was not clinically significant. Further review of her medical record revealed that her low hemoglobin and hematocrit as well as her elevated bilirubin were stable and consistent with her diagnosis of hereditary spherocytosis. Of particular note, her fasting glucose was well over the diagnostic cutoff for diabetes mellitus (Table 1). Further review of her chart showed that Mrs. J had multiple fasting glucose values in the diabetic range dating back to 4 years before her current evaluation but was never diagnosed with diabetes mellitus. Over the last 2 years, her fasting glucose had ranged from 170 to $192 \mathrm{mg} / \mathrm{dL}$ (Table 2). Her $\mathrm{HbA}_{1 \mathrm{C}}$ over this same period was consistently less than 0.05 . Given her persistently elevated fasting glucose levels, Mrs. J was diagnosed with diabetes mellitus despite her 
Table 1. Diabetes Mellitus Diagnostic Criteria ${ }^{5}$

Fasting plasma glucose of $\geq 126 \mathrm{mg} / \mathrm{dL}$

OR

Classic symptoms of diabetes (polyuria, polydipsia, and weight loss) plus random plasma glucose of $\geq 200 \mathrm{mg} / \mathrm{dL}$ OR

Two-hour plasma glucose of $\geq 200 \mathrm{mg} / \mathrm{dL}$ during an oral glucose tolerance test using WHO parameters, using a $75-\mathrm{g}$ glucose load

normal $\mathrm{HbA}_{1 \mathrm{C}}$ levels and was subsequently started on appropriate medical therapy.

\section{Discussion}

Hemoglobin, the protein molecule that transports oxygen throughout the body, resides predominantly in the red blood cell. When the red blood cell dies, the hemoglobin protein is released, broken down, and eventually excreted as bilirubin. The lifespan of the hemoglobin molecule is inherently related to the lifespan of the erythrocyte in which it resides. Under normal circumstances, this is approximately 120 days. During these 120 days, the hemoglobin molecule will be exposed to ambient glucose present in the circulation. Glycosylation or linkage of this circulating glucose to the hemoglobin molecule happens to approximately $5 \%$ of the adult hemoglobin ( $\mathrm{HbA})$ molecules. The glycosylation of $\mathrm{HbA}$ increases linearly over the lifespan of the red cell. ${ }^{2}$ In the mid to late 1950 s, it was noted that glycosylated $\mathrm{HbA}$ could be separated into at least 3 minor components designated $\mathrm{HbA}_{1 \mathrm{a}}$, $\mathrm{HbA}_{1 \mathrm{~b}}$, and $\mathrm{HbA}_{1 \mathrm{C}}$, the last of which is the most abundant. ${ }^{3}$ By measuring the amount of $\mathrm{HbA}_{1 \mathrm{C}}$ present in the circulation and taking advantage of the knowledge of the linear increase of the glyco-
Table 3. HbA $_{1 c}$ Correlation with Blood Glucose Readings $^{2}$

\begin{tabular}{lc}
\hline $\mathrm{HbA}_{1 \mathrm{c}}$ & Blood Glucose $(\mathrm{mg} / \mathrm{dL})$ \\
\hline 0.060 & 120 \\
0.070 & 150 \\
0.080 & 180 \\
0.090 & 210 \\
0.010 & 240 \\
0.011 & 270 \\
0.012 & 300 \\
0.013 & 330 \\
0.014 & 360 \\
\hline
\end{tabular}

sylation process over time, it became possible to obtain an estimate of a patient's average glucose level over the approximate 120-day lifespan of the hemoglobin protein found in the red blood cells (Table 3). By the early 1980 s, $\mathrm{HbA}_{1 \mathrm{C}}$ testing was widely available, and in subsequent years has proven to be invaluable in the management of patients with diabetes.

As useful as $\mathrm{HbA}_{1 \mathrm{C}}$ testing has become in the management of patients with diabetes, it does have notable limitations. A number of factors may confound the interpretation of the test result. Any condition that shortens the red cell lifespan, such as hereditary spherocytosis, hemolysis, sickle cell anemia, thalassemias, acute blood loss, or chronic blood loss will shorten the time of exposure of the hemoglobin protein to circulating glucose and decrease the glycosylation process. The $\mathrm{HbA}_{1 \mathrm{C}}$ measured under these circumstances would be falsely low and inaccurate. ${ }^{2}$ Conversely, any condition which lengthens the red cell lifespan or slows red cell turnover and prolongs the time of exposure of

Table 2. Historical Values from Laboratory Examinations for Mrs. J

\begin{tabular}{lccrc}
\hline Date & $\begin{array}{c}\text { Fasting Plasma } \\
\text { Glucose }(\mathrm{mg} / \mathrm{dL})\end{array}$ & Hemoglobin $\mathrm{A}_{1 \mathrm{C}}$ & Hemoglobin $(\mathrm{g} / \mathrm{dL})$ & Hematocrit \\
\hline Feb 1999 & 119 & 0.45 & 9.6 & 0.275 \\
Aug 1999 & 82 & 0.38 & 12.4 & 0.351 \\
Dec 2000 & & 0.41 & 11.8 & 0.343 \\
Apr 2001 & 137 & 0.41 & 10.9 & 0.296 \\
Mar 2002 & 136 & 0.46 & 10.3 & 0.296 \\
Apr 2003 & 192 & 0.50 & 11.4 & 0.330 \\
Apr 2004 & 170 & 0.44 & 10.6 & 0.297 \\
Mar 2005 & 187 & 0.48 & & \\
\hline
\end{tabular}


the hemoglobin protein to circulating glucose, such as iron deficiency anemia, vitamin $B_{12}$ deficiency anemia, or folate deficiency anemia, would increase the glycosylation process and lead to a falsely high and inaccurate $\mathrm{HbA}_{1 \mathrm{C}}$ level. ${ }^{4}$ With the possibility of both falsely low and falsely high $\mathrm{HbA}_{1 \mathrm{C}}$ levels, clinicians must interpret the test cautiously taking into account other pertinent data.

Although a high, low, or normal $\mathrm{HbA}_{1 \mathrm{C}}$ can be an extremely useful piece of information when used in the appropriate context, it is not currently recognized as a diagnostic test for patients with diabetes. During their 1997 report, the Expert Committee on the Diagnosis and Classification of Diabetes Mellitus recognized the value of the $\mathrm{HbA}_{1 \mathrm{C}}$ test in the management of diabetes but recommended against its use as a diagnostic test. ${ }^{5}$ This recommendation was supported in 2003 by an Expert Committee update. ${ }^{6}$

In cases such as Mrs. J's, in which her red cells have a shortened lifespan because of her hereditary spherocytosis making the $\mathrm{HbA}_{1 \mathrm{C}}$ test unreliable, a fructosamine analysis can be useful. This test measures the glycosylation of serum proteins such as albumin rather than hemoglobin. Like $\mathrm{HbA}_{1 \mathrm{C}}$, this test can be used to estimate the average blood glucose over time. ${ }^{7}$ However, because of the shorter lifespan of serum proteins, fructosamine analysis correlates only with the average blood glucose over the previous 2 to 3 weeks. ${ }^{8}$ Thus, a fructosamine analysis would need to be performed monthly to acquire the same information obtained with quarterly $\mathrm{HbA}_{1 \mathrm{C}}$ levels. There are also other disadvantages to using the fructosamine assay. Fructosamine values can vary with such changes in the synthesis or clearance of serum proteins as occurs with acute illness or liver disease. In addition, elevated uric acid levels, elevated bilirubin levels, or the presence of heparin may alter the results ${ }^{2}{ }^{8}$ The assay should not be performed if the serum albumin level is $\leq 3.0 \mathrm{mg} / \mathrm{dL}$, because there is ongoing debate on whether to correct the results for serum protein or albumin levels. Finally, unlike the $\mathrm{HbA}_{1 \mathrm{C}}$ test, the fructosamine analysis has not been as extensively used or studied and consequently has not been proven to correlate with diabetic complications. ${ }^{8}$ Although certainly not a perfect test, when used and interpreted appropriately, the fructosamine assay can be an important instrument in clinical situations where the $\mathrm{HbA}_{1 \mathrm{C}}$ is unreliable.
In addition to $\mathrm{HbA}_{1 \mathrm{C}}$ and fructosamine assays, monitoring daily home and office blood glucose levels of patients with diabetes is another appropriate management strategy. The benefit of blood glucose monitoring is that it gives a point of care result and allows for more timely changes in therapy. The levels of a patient's blood glucose monitoring can be used alone or in conjunction with $\mathrm{HbA}_{1 \mathrm{C}}$ and fructosamine assays to optimize the control of a patient's diabetes. Blood glucose monitoring does require a motivated and compliant patient and additional supplies, which may be construed by some as a barrier.

Although Mrs. J's fasting glucose levels had clearly met diagnostic criteria for diabetes mellitus for quite some time, her $\mathrm{HbA}_{1 \mathrm{C}}$ levels were never elevated because of the decreased number and shortened lifespan of her erythrocytes (Tables 1 and 2). It is likely that the falsely reassuring $\mathrm{HbA}_{1 \mathrm{C}}$ values contributed to the delay in diagnosis of diabetes mellitus in this case. This should serve to remind clinicians to interpret each test result in context with the other available data. A literature review revealed another similar case reported in 2003 by Liew and Cheah ${ }^{9}$ involving an acutely ill hospitalize patient with hereditary spherocytosis who was diagnosed with diabetes mellitus as a result of significantly elevated glucose levels meeting diagnostic criteria for diabetes mellitus despite the normal $\mathrm{HbA}_{1 \mathrm{C}}$ level.

\section{Summary}

Clear criteria exist for the diagnosis of diabetes mellitus (Table 1). In Mrs. J's case, a coexisting disorder, hereditary spherocytosis, interfered with the accuracy of a test used to manage and monitor her other disorder, diabetes. This case illustrates the inherent inaccuracy of the $\mathrm{HbA}_{1 \mathrm{C}}$ assay in the setting of hemolytic disorders such as hereditary spherocytosis or any condition that alters the life span of the red blood cell. Clinicians should remember the importance of established diagnostic criteria for the diagnosis of diabetes mellitus and the need for the use of alternative methods, such as a fructosamine assay or blood glucose monitoring, when appropriate, to achieve long-term therapeutic success.

\section{References}

1. Centers for Disease Control and Prevention. National diabetes fact sheet: general information and 
national estimates on diabetes in the United States, 2005 [monograph on the Internet]. Atlanta: US Department of Health and Human Services, Centers for Disease Control and Prevention; 2005 [cited 2005 Dec 26]. Available from http://www.diabetes. org/uedocuments/NationalDiabetesFactSheetRev. pdf.

2. Diabetes mellitus. In: Henry JB, ed. Clinical diagnosis and management by laboratory methods. 20th ed. Philadelphia: WB Saunders; 2001. p. 215-8 and 561.

3. Goldstein DE, Little RR, Lorenz RA, et al. Tests of glycemia in diabetes. Diabetes Care 2004;27:1761-73.

4. McCulloch DK. Estimation of blood glucose control in diabetes mellitus. Up to Date, online version 14.2, 2006.

5. Anonymous. Report of the Expert Committee on the
Diagnosis and Classification of Diabetes Mellitus. Diabetes Care 1997;20:1183-97.

6. Genuth S, Alberti KG, Bennett P, et al; Expert Committee on the Diagnosis and Classification of Diabetes Mellitus. Follow-up report on the diagnosis of diabetes mellitus. Diabetes Care 2003;26:3160-7.

7. Ghacha R, Sinha AK, Karkar AM. $\mathrm{HbA}_{1 \mathrm{C}}$ and serum fructosamine as markers of the chronic glycemic state in type 2 diabetic hemodialysis patients. Dial Transplant 2001;30:214-7.

8. American Diabetes Association. Tests of glycemia in diabetes (Position Statement). Diabetes Care 2002; 25:S97-9.

9. Liew CF, Cheah JS. Hereditary spherocytosis, a pitfall in the assessment of glycaemic control. Singapore Med J 2003;44:94-7. 